\title{
IQN path ASBL report from the first European cfDNA consensus meeting: expert opinion on the minimal requirements for clinical ctDNA testing
}

\author{
Zandra C. Deans $^{1}$ (D) $\cdot$ Rachel Butler $^{2} \cdot$ Melanie Cheetham $^{3}$ - Elisabeth M. C. Dequeker ${ }^{4,5} \cdot$ Jennifer A. Fairley ${ }^{1}$. \\ Francesca Fenizia ${ }^{6}$. Jacqueline A. Hall ${ }^{7}$. Cleo Keppens ${ }^{4}$ - Nicola Normanno ${ }^{6}$. Ed Schuuring ${ }^{8}$ - Simon J. Patton ${ }^{3}$
}

Received: 21 June 2018 / Revised: 8 February 2019 / Accepted: 2 April 2019 / Published online: 26 April 2019

(C) The Author(s) 2019

\begin{abstract}
Liquid biopsy testing is a new laboratory-based method that detects tumour mutations in circulating free DNA (cfDNA) derived from minimally invasive blood sampling techniques. Recognising the significance for clinical testing, in 2017, IQN Path provided external quality assessment for liquid biopsy testing. Representatives of those participating laboratories were invited to attend a workshop to discuss the findings and how to achieve quality implementation of cfDNA testing in the clinical setting, the discussion and outcomes of this consensus meeting are described below. Predictive molecular profiling using tumour tissue in order to select cancer patients eligible for targeted therapy is now routine in diagnostic pathology. If insufficient tumour tissue material is available, in some circumstances, recent European Medicines Agency (EMA) guidance recommends mutation testing with plasma cfDNA. Clinical applications of cfDNA include treatment selection based on clinically relevant mutations derived from pre-treatment samples and the detection of resistant mutations upon progression of the disease. In order to identify tumour-related mutations in amongst other nucleic acid material found in plasma samples, highly sensitive laboratory methods are needed. In the workshop, we discussed the variable approaches taken with regard to cfDNA extraction methods, the tests, and considered the impact of false-negative test results. We explored the lack of standardisation of complex testing procedures ranging from plasma collection, transport, processing and storage, cfDNA extraction, and mutation analysis, to interpretation and reporting of results. We will also address the current status of clinical validation and clinical utility, and its use in current diagnosis. This workshop revealed a need for guidelines on with standardised procedures for clinical cfDNA testing and reporting, and a requirement for cfDNA-based external quality assessment programs.
\end{abstract}

Keywords ctDNA $\cdot \mathrm{cfDNA} \cdot$ Liquid biopsy testing

This article is part of the Topical Collection on Quality in Pathology

Zandra C. Deans

sandi.deans@ed.ac.uk

1 UK NEQAS for Molecular Genetics, Department of Laboratory Medicine, Royal Infirmary of Edinburgh, Little France Crescent, Edinburgh EH16 4SA, UK

2 All Wales Genetic Laboratory, Institute of Medical Genetics, University Hospital of Wales, Heath Park, Cardiff CF14 4XW, UK

3 European Molecular Genetics Quality Network, Manchester Centre for Genomic Medicine, St Mary's Hospital, Manchester M13 9WL, UK
4 Biomedical Quality Assurance Research Unit, Department of Public Health and Primary Care, KU Leuven, Leuven, Belgium

5 University Hospital of Leuven, Leuven, Belgium

6 Cell Biology and Biotherapy Unit, Istituto Nazionale Tumori "Fondazione G. Pascale"-IRCCS, Naples, Italy

7 International Quality Network for Pathology (IQN Path ASBL), 3A Sentier de l'Esperance, 1474 Luxembourg, Luxembourg

8 Department of Pathology, University of Groningen, University Medical Center of Groningen, Groningen, The Netherlands 


\section{Introduction}

The National Cancer Institute defines liquid biopsy as a test performed on blood samples in order to look for cancer cells from a tumour that are circulating in the blood, or for pieces of DNA from tumour cells that are in the blood [1]. Being a noninvasive, cost-effective procedure, which rapidly detects and monitors molecular biomarkers in cancer patients, analysis of plasma cfDNA testing has shown great promise to become a useful clinical tool. It is particularly useful in identifying targeted treatments and monitoring tumour response to therapy.

However, plasma cfDNA testing is not without challenges: establishment of optimal timings between blood draw and blood processing, optimising DNA extraction procedures, identifying appropriate analysis methods and ensuring accurate interpretation of results. With these issues in mind, IQN Path, a network of quality assessment experts with an interest in cancer biomarker testing, collected data on liquid biopsy testing in Europe in 2017 [2] provided an external quality assessment [3] and organised a cfDNA workshop which was attended by European key opinion leaders. The purpose of the workshop was to summarise the current limited knowledge on liquid biopsy testing and to establish a white paper to emphasise the need for standardisation of the implementation cfDNA testing in clinical practice. This article summarises the workshop discussions.

\section{Current applications of cfDNA mutation testing}

The current clinical applications of cfDNA mutation testing are the identification targeted therapies in non-small cell lung cancer (NSCLC) by testing for epidermal growth factor receptor (EGFR) mutations, and the assessment of Kirsten RAt Sarcoma (KRAS), Neuroblastoma RAS viral oncogene homologue (NRAS) and v-Raf murine sarcoma viral oncogene homologue $\mathrm{B}(B R A F)$ mutation status in patients with colorectal cancer (CRC), in situations when molecular testing is not feasible on tissue due to insufficient/inadequate material or inability to perform a biopsy [4]. Clinical trials have shown that analysis of serial cfDNA samples during cancer treatment can monitor tumour response and identify early emergence of any resistance mechanisms [5-8]. Following targeted therapy, cfDNA testing can identify treatment-resistant mutations. In the event that cfDNA plasma testing does not detect a mutation, a solid tumour tissue biopsy and the cfDNA plasma test should be conducted concurrently, as the results may help inform recommendations for novel treatment options.

Different tumour types raise their own particular issues [9]. For example, in patients with NSCLC who have brain metastases or intra-thoracic disease, the chances of detecting cfDNA mutations in plasma are reduced [10]. In patients with gastrointestinal stromal tumours (GIST), targetable KIT mutations in pre-treatment tumour biopsies are not detected in one in nine patients with localised or local advanced disease, whereas in 13 of 14 cases with metastasized advanced GIST, KIT mutations are detected in pre-treatment plasma [6]. In patients with CRC [7, 11-13] and with NSCLC regarding the detection of resistance mutations upon progression on tyrosine kinase inhibitors $[14,15]$, a key issue is the sensitivity of the different assays.

Today, the clinical utility of cfDNA testing that is required to evaluate whether clinical outcome for patients who were treated based on the test has improved compared to those not tested, and has not been performed for most tumour types despite major achievements regarding analytical validity and clinical validity $[16,17]$. Therefore, cfDNA testing is not appropriate for diagnosis (without tissue diagnosis). The only two FDA-approved cfDNAbased tests with clinical utility are the cobas EGFR Mutation Test v2 (Roche Diagnostics) detecting EGFR mutations in cfDNA from patients with lung cancer [3, $18]$ and the Epi proColon assay (Epigenomics AG) for the detection of SEPT9 promoter methylation in cfDNA from patients undergoing screening for CRC [19].

However, the expectations of the clinical applications of cfDNA testing are high. If implemented well, performed at high quality (according to ISO 15189) [20], it can be a reliable, robust, reproducible, cost-effective and accurate test with a fast turn-around time. It is anticipated that in the future, a trend towards multiplexed and quantitative cfDNA testing methods as these will yield even larger amounts of useful clinical information.

\section{Sample collection and processing}

The volume of blood required for cfDNA analysis is dependent upon the testing methodology but generally ranges between 6 and $10 \mathrm{ml}$. Clearly, handling of blood samples impact on the quality of the cfDNA testing and on the downstream results and tubes should be spun and processed as soon as possible. Therefore, tubes selected for blood collection must be appropriate to maintain the integrity of the sample, taking into consideration the time between the blood draw and laboratory processing, the availability of any storage facilities and the mechanism of transport to the processing laboratory. Current methods typically involve blood collection in EDTA anti-coagulant tubes, storage at $4{ }^{\circ} \mathrm{C}$, and transportation to the pathology laboratory where the sample is processed and stored at $-80{ }^{\circ} \mathrm{C}$, all within a timeframe of $6 \mathrm{~h}$. However, these options are not always feasible; therefore, the use of tubes containing preservatives to prevent haemolysis and to reduce the 
degradation of cfDNA is becoming increasingly common practice to allow an extended period of time before blood must be processed. Laboratories must apply acceptance criteria to ensure that received samples are suitable for cfDNA mutation testing. Processing protocols should entail a double centrifugation protocol, including initial slow centrifugation, with the eluted plasma subjected to a second fast centrifugation. The resultant plasma layer can be used for cfDNA extraction immediately or can be stored either at $-20{ }^{\circ} \mathrm{C}$ for fewer than 5 days or at $-80{ }^{\circ} \mathrm{C}$ for longer storage. Freeze thawing sample aliquots is not recommended. Table 1 summarises the advantages and disadvantages of current options.

Table 1 Summary of the advantages and disadvantages of available blood collection tubes

\begin{tabular}{|c|c|c|c|}
\hline Tube type & Examples & Advantages & Disadvantages \\
\hline $\begin{array}{l}\text { EDTA } \\
\text { anti-- } \\
\text { coagulant }\end{array}$ & $\begin{array}{l}\cdot \text { EDTA K K }_{2} \\
\cdot \text { EDTA K }_{3}\end{array}$ & $\begin{array}{l}\text { - Inexpensive } \\
\text { - Readily } \\
\text { available } \\
\text { - Follows } \\
\text { standard } \\
\text { processes for } \\
\text { handling of } \\
\text { blood tubes }\end{array}$ & $\begin{array}{l}\text { - Processing within } \\
6 \mathrm{~h}\end{array}$ \\
\hline Preservatives & $\begin{array}{l}\text { - } \\
\text { StreckCell-f- } \\
\text { ree DNA } \\
\text { BCT } \\
\text { - Qiagen } \\
\text { PAXgene } \\
\text { Blood } \\
\text { ccfDNA } \\
\text { tubes } \\
\text { - Roche } \\
\text { cFDNA } \\
\text { tubes } \\
\text { - ThermoFisher } \\
\text { Liquid } \\
\text { Biopsy } \\
\text { Blood } \\
\text { collection kit } \\
\text { - Norgen } \\
\text { cfDNA } \\
\text { Preservation } \\
\text { tube } \\
\text { - MagBio } \\
\text { Blood } \\
\text { STASIS } \\
\text { 21ccfDNA } \\
\text { tubes } \\
\text { - Biomatrica } \\
\text { LBgard } \\
\text { blood tubes } \\
\text { - CellSave } \\
\text { Preservation } \\
\text { tubes } \\
\text { (Janssen } \\
\text { Diagnostics) }\end{array}$ & $\begin{array}{l}\text { - Storage and } \\
\text { transport at } \\
\text { ambient } \\
\text { temperature } \\
\text { - Provides up to } \\
72 \mathrm{~h} \text { for } \\
\text { processing } \\
\text { - Readily } \\
\text { available }\end{array}$ & $\begin{array}{l}\text { - Expensive } \\
\text { - Out of step with } \\
\text { usual practice for } \\
\text { handling of blood } \\
\text { tubes i.e. storage } \\
\text { at ambient } \\
\text { temperature } \\
\text { - Some only } \\
\text { available as a } \\
\text { glass tube }\end{array}$ \\
\hline
\end{tabular}

\section{DNA extraction}

Plasma samples can contain a variable amount of high molecular weight (HMW) DNA as a result of haemolysis during processing. In contrast, plasma ctDNA (circulating tumour) fragments have an average size of 132-1450 base pairs (bp) corresponding to mononucleosome-protected DNA $[17,21]$. With growing interest in cfDNA-based diagnostics, a number of cfDNA-focused extraction kits are available from various manufacturers (Table 2). However, none of the current cfDNA extraction methodologies enrich either ctDNA or the nucleosome-protected DNA fragments. Studies comparing cfDNA extraction methods and kits revealed large differences in total DNA yield [22-24]. These findings may be due to a variety of reasons, including variations in extraction methodology, plasma input and elution volume, or that with low volumes of available plasma cfDNA, there is a tendency to load larger plasma volumes and elute the cfDNA fragment with the lowest volume to maximise concentration. So, to select the optimal cfDNA extraction kit, factors such as the extraction method, time, throughput and price should be considered.

To compare the performance of different cfDNA extraction methods, most studies focus on cfDNA yield, quantifying the yield with techniques such as fluorospectroscopy, fluorometry and quantitative real-time PCR (qPCR). In general, quantification of DNA elutes shows a significant correlation with qPCR [23], while non-double-stranded DNA measurement assays do not.

High levels of nucleosome-protected DNA from nontumour tissues in addition to HMW DNA can complicate ctDNA molecular analysis by increasing the rate of false-negatives. Hence, the integrity of any extracted cfDNA should be tested. However, typical methods that measure cfDNA quantity do not assess extracted DNA integrity. Integrity testing options include fragment analysis which employs capillary electrophoresis to determine DNA fragment length: The size of DNA fragments is used to evaluate the relative amount of nucleosome-protected 140-160 bp DNA fragments compared to HMW DNA and DNA degradation [22, 23]. More recently, amplifiable DNA concentrations and the fragment size have been measured using very small amounts of cfDNA in various single-tube multiplex digital droplet PCR (ddPCR) assays [6, $25,26]$.

So, in the case of insufficient cfDNA, the cfDNA should be quantified using a double-stranded DNA method before proceeding to PCR or sequencing analysis. In addition, as various factors can complicate the molecular analysis of cfDNA, the integrity of any extracted cfDNA should be estimated. Finally, the amount of ctDNA can not only be influenced by preanalytical procedures such as haemolysis, centrifugation and cfDNA extraction procedures, but it has been reported that ctDNA levels differ significantly between various tumour types, stages of disease, tumour volume and stages of 
Table 2 Examples of currently available cfDNA extraction methods

\begin{tabular}{ll}
\hline cfDNA extraction kit & Manufacturer \\
\hline QIAamp® circulating Nucleic Acid Kit & Qiagen \\
QIAamp® DNA Blood Mini Kit & Qiagen \\
EZ1® ccfDNA Kit & Qiagen \\
QIAsymphony PAXgene Blood ccfDNA Kit & Qiagen \\
QIAsymphony DSP Circulating DNA Kit & Qiagen \\
QIAamp® MinElute® ccfDNA & Qiagen \\
cfDNA isolatie van Quick-cfDNA ${ }^{\text {TM }}$ Serum and Plasma DNA Miniprep Kit & Zymo Research \\
Maxwell® RSC ccf Plasma Kit & Promega \\
Cobas® cfDNA Sample Preparation Kit & Roche Diagnostics \\
NucleoSpin® Kit & Macherey-Nagel \\
MagNA Pure Isolation System & Roche Diagnostics \\
Plasma ccf DNA purification kit & Norgen BioTek \\
Chemagic cfDNA isolation kit & Perkin-Elmer \\
FitAmp Plasma/Serum DNA isolation kit & Epigentek \\
PME free circulating DNA extraction KIT & Analytik Jena \\
EpiQuick ${ }^{\text {TM }}$ cfDNA Isolation Easy Kit & Epigentek \\
NEXTprep-MagTM cfDNA Kit & Bio Scientific/PerkinElmer \\
IdyllaTM ctKRAS Plasma Test (DNA extraction is part of detection-test) & Biocartis \\
\hline
\end{tabular}

treatment $[6,9]$. Different levels of total cfDNA are also influenced upon extreme exercise, infectious disease and age [27]. In short, we should realise that today, the dynamics of the release of DNA from cancer cells into the circulation, the mechanism of clearance as well as half-life of cfDNA, are still poorly understood.

\section{Testing methods}

Plasma often contains very low levels of cfDNA; therefore, methods are needed, different from those used for targeted detection of defined oncogenic variants in tissue biopsy, with a very high analytical sensitivity $(0.01-0.1 \%)$. Assays for the detection of the same variants in cfDNA include amplified refractory mutation system (ARMS), allele-specific quantitative PCR, PCR with peptide nucleic acid clamps, nextgeneration sequencing (NGS), BEAMing and ddPCR $[5,17$, 28, 29]. These assays should be optimised for sensitivity in order to detect cfDNA which may be present in lower concentrations than DNA isolated from cancer tissue [30]. Many laboratories have focused on improving cfDNA assay specificity, in order to make it more useful as a screening tool. A meta-analysis of 20 studies demonstrated that specificities achieved using cfDNA were comparable to solid tissue genotyping [31]. The performance of NGS, which enables broader gene profiling, has also been evaluated using cfDNA with some studies showing similar sensitivities and specificities when compared to single-gene assays [32-35]. In contrast, an international pilot External Quality
Assessment (EQA) scheme observed a higher methodspecific error rate for NGS compared to ddPCR and commercial kits [3].

The choice of assay will depend on multiple factors including clinical requirements, throughput, specificity, sensitivity, and access to equipment, expertise and budget. Table 3 summarises some of the commonly used assays for detecting clinical-relevant $E G F R$ variants in cfDNA derived from NSCLC. The clinical oncology demand for testing of variants other than EGFR will help establish multigene testing as routine practise in future.

\section{Reporting results}

Reporting the results of plasma cfDNA mutation testing should follow standard guidelines for reporting of molecular pathology results [36, 37] and adhere to the ISO15189 standard for medical laboratories [20]. Reports should be clear and concise within a maximum of two pages. It should be clearly stated that cfDNA testing has been performed and include two patient-specific identifiers, a sample identifier and the sample type tested. Pagination should be used and included with the date and time of sampling, a clear statement of the results, details of the testing method performed, limitations of the test including sensitivity of the assay, reason for referral, appropriate interpretation of results and details of the reporter and authoriser. Genotyping results should be given according to Human Genome Variation Society (HGVS) nomenclature 

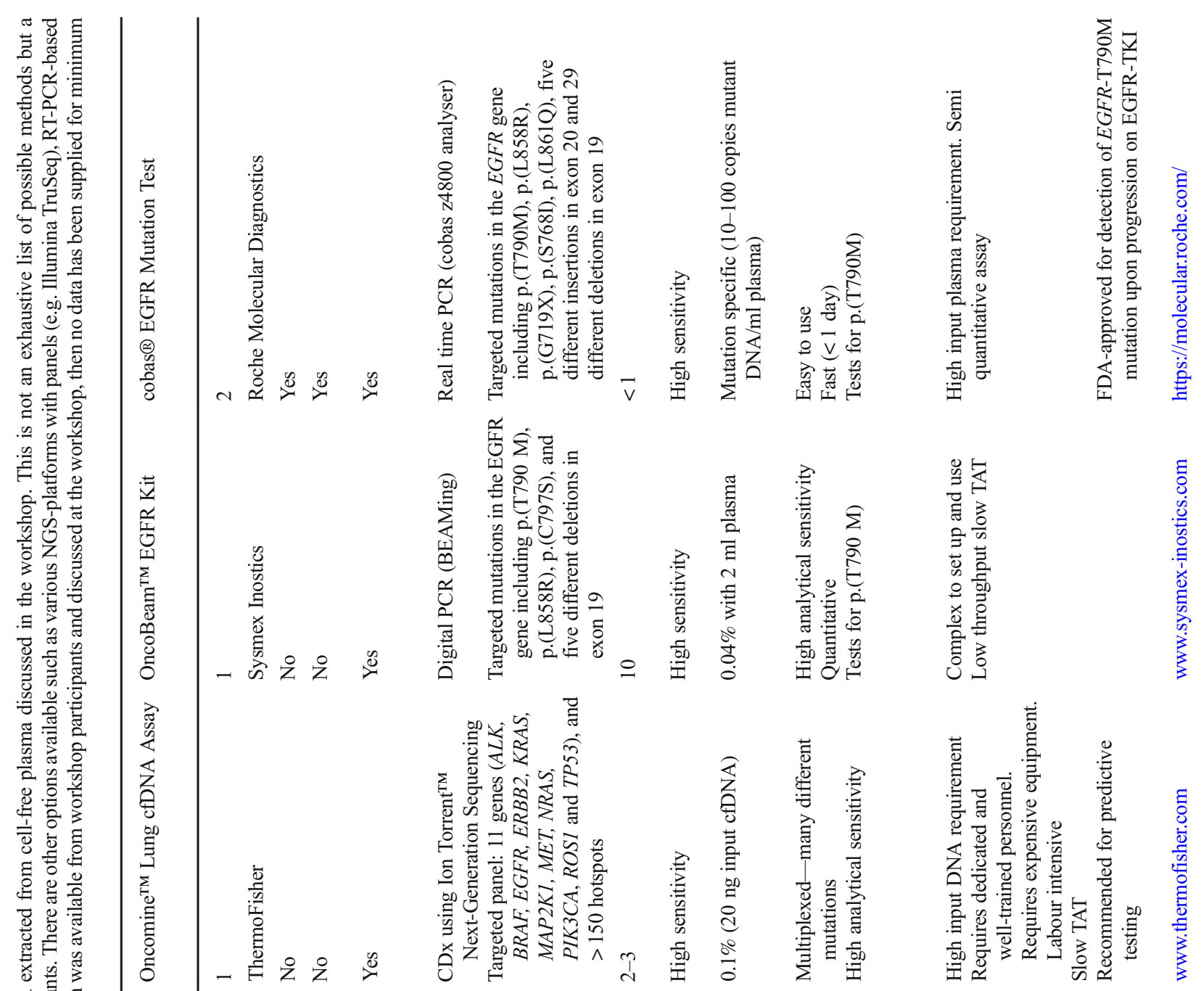

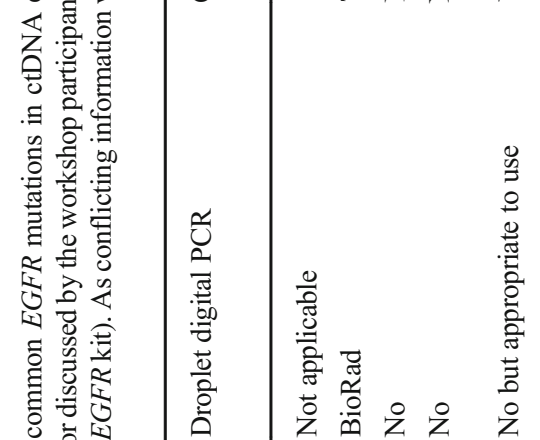

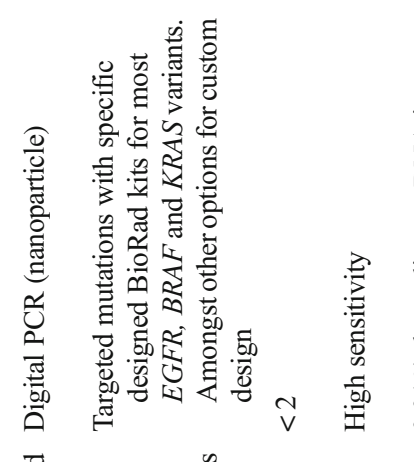

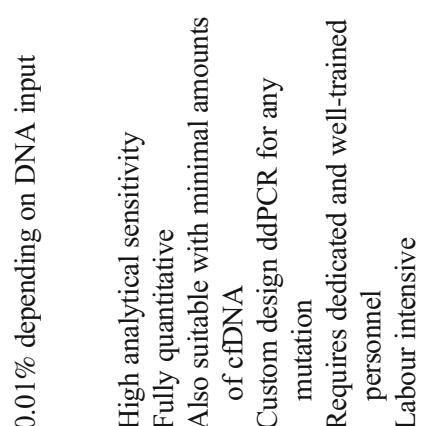

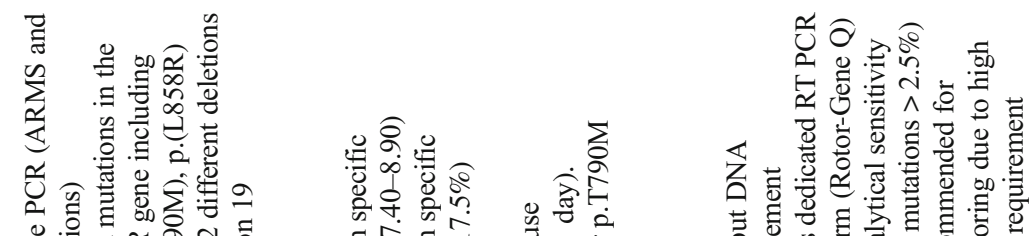

क

窟总焉

I

MII

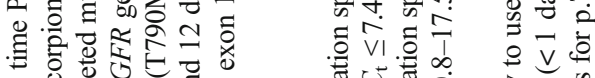

wa

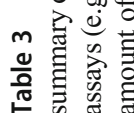
旁量

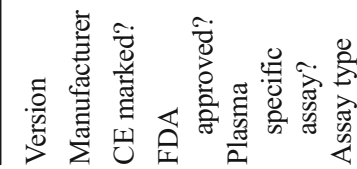

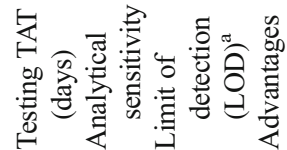

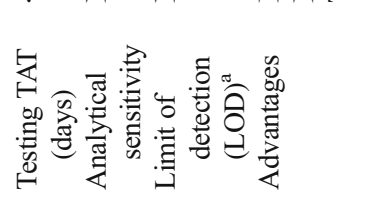

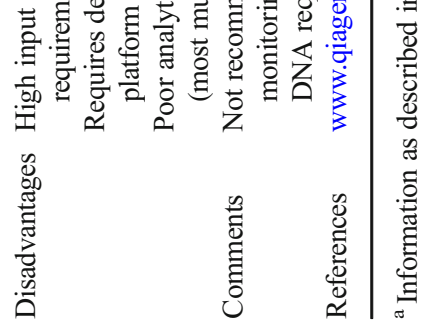


[38], and the predicted protein change should be presented with appropriate reference sequences.

Further details may be included if it pertains to the result, for example, the tube type used for blood collection or if there is evidence of haemolysis. These details should be noted within the molecular testing laboratory even if not included on the external report.

The sensitivity of the method of cfDNA analysis should be stated. As the total amount of cfDNA will vary, it is recommended that both the variant allele frequency (VAF) and the amount of mutant copies per milliliter of plasma are reported. Standardisation is encouraged to aid result interpretation and for the comparison of data between laboratories. Ultimately, the total cfDNA prior to the analysis of mutations and the limit of sensitivity of the assay are useful additions to any reporting. Any previous molecular analyses should also be outlined and previously detected mutations re-stated, for subsequent analysis may include the detection of primary mutations.

The interpretation of the molecular result depends on the gene analysed, the tumour type and the clinical context of the gene-drug interaction. However, the analysis of cfDNA requires additional consideration, as the presence or absence of cfDNA is unknown in the absence of a detectable mutation. The detection of a mutation will generally lead to a simple interpretation of the mutation present result. However, a mutation absent result could be due to a variety of reasons including:

- The mutation is not detected and is therefore a true negative.

- Insufficient sample of ctDNA giving a possible false negative.

- The sampling method destroyed any ctDNA giving a possible false negative.

- The analytical method is insufficiently sensitive to detect low levels of mutant ctDNA, resulting in a false negative.

When no mutation is detected, the report should either include a remark that "mutation not detected does not rule out the presence of a mutation because the analysis depends on LOD of the test, and quality and quantity of the input cfDNA" or contain specific information on the quality control metrics of the assays regarding the LOD of the tested sample. For example, for ddPCR, this should be based on the number of mutant droplets in no template controls divided by the total number of positive droplets. A "mutation absent" result must be treated with caution, and the above possibilities should be referred to, and repeat sampling recommended, preferably by biopsy. Dependent on the gene, tumour type and clinical context, additional controls may be included which may aid interpretation, as previously described.

\section{Quality considerations}

High-quality cfDNA testing procedures yield high quality results. Validation and verification of laboratory methods and procedures ensure a safe and useful service for clinicians and patients. However, errors in the pre-analytical phase can lead to false-positive or false-negative results which can result in misdiagnosis and inappropriate treatment. There are a number of issues to consider in the establishment and maintenance of high-quality processes.

Laboratories must have sample acceptance criteria which are then communicated to the clinicians requesting and collecting samples. Sample storage must be documented and monitored, and further sample preparation procedures validated. Methods should be optimised for sensitivity and cost-effectiveness. Test development, assessment of utility and performance specification should be properly documented.

Test validation should include different kinds of variants such as point mutations or small insertions and deletions, as well as positive and negative internal quality controls, the type of which largely depends on the methodology used. Validation should focus on samples that have been processed through all clinical workflows, and critically on cfDNA samples with variants at the limits of sensitivity. In addition, to permit the reliable detection of rare clinically relevant variants, regular external and internal validation should assess and monitor the quality of test results and, when required, modify existing methods and procedures.

Commercially available reference standards can be used as internal quality controls. To monitor the performance of each test, it is recommended that samples harbouring a different percentage of mutant allele up to the limit of detection are used. However, it should be noted that cell line and synthetic materials may not be optimal substitutes for ctDNA derived from blood or plasma [39].

Laboratories are advised to optimise their workflow design and embrace quality control parameters. To avoid contamination, different test phases should be performed in contained compartments. Turnaround time should be closely monitored, and action taken the clinically acceptable timeframe is exceeded. Detailed standard operating procedures are required, and all personnel should be adequately trained in these and kept informed of any changes. Laboratories are encouraged to regularly demonstrate that their testing procedures deliver accurate and reliable results by implementing regular internal audits and to participate in external quality assurance. We strongly recommend that all processing steps should be performed and monitored according to the requirements of ISO15189 [20].

Finally, when outsourcing any part of cfDNA analysis to an external laboratory, the referring laboratory must be responsible for documenting procedures used for the selection and evaluation of the external laboratory and should monitor the quality of performance and ensure that it is competent to perform the required testing. 


\section{Conclusion}

It was clear from the workshop that many laboratories in Europe already perform cfDNA testing or are planning to adopt it for NSCLC for treatment selection and resistance monitoring. This paper summarises the discussions about cfDNA testing in clinical practice from the workshop and encompasses several aspects of cfDNA mutation testing, including technical considerations, quantity and quality of extracted cfDNA, the advantages and disadvantages of different testing methods, reporting of results and quality assurance and quality control. The workshop highlighted the different approaches taken by testing laboratories through the pathway, end to end, i.e. from blood collection, cfDNA extraction method, assays performed and reporting of the results. cfDNA testing has the potential for broader applications in clinical practice in the future, and we anticipate that the use of multiplex methods will continue to increase as larger volumes of data can be generated from one sample that may provide additional insights into treatment options for patients.

Funding The workshop was funded by IQN Path.

\section{Compliance with ethical standards}

Conflict of interest The authors declare the following conflict of interest:

Schuuring E performed lectures for Illumina, Novartis, Pfizer, BioCartis; is consultant in advisory boards for AstraZeneca, Pfizer, Novartis, BioCartis; and received financial support from Roche, Biocartis, BMS, Pfizer (all fees to the Institution).

Deans ZC is consultant in advisory boards for AstraZeneca and Roche.

Butler R is a consultant in advisory boards for AstraZeneca, Novartis, Roche, Pfizer, Bristol-Myers Squibb.

All authors contributed equally to the design and delivery of the workshop, and preparation of the manuscript.

Ethical approval The authors comply with the Ethical Standards.

Open Access This article is distributed under the terms of the Creative Commons Attribution 4.0 International License (http:// creativecommons.org/licenses/by/4.0/), which permits unrestricted use, distribution, and reproduction in any medium, provided you give appropriate credit to the original author(s) and the source, provide a link to the Creative Commons license, and indicate if changes were made.

\section{References}

1. Definition of liquid biopsy - NCI Dictionary of Cancer Terms National Cancer Institute. https://www.cancer.gov/publications/ dictionaries/cancer-terms/def/liquid-biopsy. Accessed 28 Jan 2019

2. Deans ZC, Williams H, Dequeker EMC et al (2017) Review of the implementation of plasma ctDNA testing on behalf of IQN path ASBL: a perspective from an EQA providers' survey. Virchows Arch 471:809-813. https://doi.org/10.1007/s00428-017-2222-Z
3. Keppens C, Dequeker EMC, Patton SJ et al (2018) International pilot external quality assessment scheme for analysis and reporting of circulating tumour DNA. BMC Cancer 18. https://doi.org/10. 1186/s12885-018-4694-x

4. Lindeman NI, Cagle PT, Aisner DL, Arcila ME, Beasley MB, Bernicker EH, Colasacco C, Dacic S, Hirsch FR, Kerr K, Kwiatkowski DJ, Ladanyi M, Nowak JA, Sholl L, TempleSmolkin R, Solomon B, Souter LH, Thunnissen E, Tsao MS, Ventura CB, Wynes MW, Yatabe Y (2018) Updated molecular testing guideline for the selection of lung Cancer patients for treatment with targeted tyrosine kinase inhibitors: guideline from the College of American Pathologists, the International Association for the Study of Lung Cancer, and the. Arch Pathol Lab Med 142: 321-346. https://doi.org/10.5858/arpa.2017-0388-CP

5. Diaz LA, Bardelli A (2014) Liquid biopsies: genotyping circulating tumor DNA. J Clin Oncol 32:579-586. https://doi.org/10.1200/ JCO.2012.45.2011

6. Boonstra PA, ter Elst A, Tibbesma M, Bosman LJ, Mathijssen R, Atrafi F, van Coevorden F, Steeghs N, Farag S, Gelderblom H, van der Graaf WTA, Desar IME, Maier J, Overbosch J, Suurmeijer AJH, Gietema J, Schuuring E, Reyners AKL (2018) A single digital droplet PCR assay to detect multiple KIT exon 11 mutations in tumor and plasma from patients with gastrointestinal stromal tumors. Oncotarget 9:13870-13883. https://doi.org/10.18632/ oncotarget. 24493

7. Siravegna G, Mussolin B, Buscarino M, Corti G, Cassingena A, Crisafulli G, Ponzetti A, Cremolini C, Amatu A, Lauricella C, Lamba S, Hobor S, Avallone A, Valtorta E, Rospo G, Medico E, Motta V, Antoniotti C, Tatangelo F, Bellosillo B, Veronese S, Budillon A, Montagut C, Racca P, Marsoni S, Falcone A, Corcoran RB, di Nicolantonio F, Loupakis F, Siena S, SartoreBianchi A, Bardelli A (2015) Clonal evolution and resistance to EGFR blockade in the blood of colorectal cancer patients. Nat Med 21:795-801. https://doi.org/10.1038/nm.3870

8. Normanno N, Rachiglio AM, Lambiase M, Martinelli E, Fenizia F, Esposito C, Roma C, Troiani T, Rizzi D, Tatangelo F, Botti G, Maiello E, Colucci G, Ciardiello F (2015) Heterogeneity of KRAS, NRAS, BRAF and PIK3CA mutations in metastatic colorectal cancer and potential effects on therapy in the CAPRI GOIM trial. Ann Oncol 26:1710-1714. https://doi.org/10.1093/annonc/ mdv176

9. Bettegowda C, Sausen M, Leary RJ, Kinde I, Wang Y, Agrawal N, Bartlett BR, Wang H, Luber B, Alani RM, Antonarakis ES, Azad NS, Bardelli A, Brem H, Cameron JL, Lee CC, Fecher LA, Gallia GL, Gibbs P, le D, Giuntoli RL, Goggins M, Hogarty MD, Holdhoff M, Hong SM, Jiao Y, Juhl HH, Kim JJ, Siravegna G, Laheru DA, Lauricella C, Lim M, Lipson EJ, Marie SKN, Netto GJ, Oliner KS, Olivi A, Olsson L, Riggins GJ, Sartore-Bianchi A, Schmidt K, Shih M, Oba-Shinjo SM, Siena S, Theodorescu D, Tie J, Harkins TT, Veronese S, Wang TL, Weingart JD, Wolfgang CL, Wood LD, Xing D, Hruban RH, Wu J, Allen PJ, Schmidt CM, Choti MA, Velculescu VE, Kinzler KW, Vogelstein B, Papadopoulos N, Diaz LA (2014) Detection of circulating tumor DNA in early- and late-stage human malignancies. Sci Transl Med 6:224ra24-224ra24. https://doi.org/10.1126/scitranslmed.3007094

10. De Mattos-Arruda L, Mayor R, Ng CKY et al (2015) Cerebrospinal fluid-derived circulating tumour DNA better represents the genomic alterations of brain tumours than plasma. Nat Commun 6:8839. https://doi.org/10.1038/ncomms9839

11. Grasselli J, Elez E, Caratù G, Matito J, Santos C, Macarulla T, Vidal J, Garcia M, Viéitez JM, Paéz D, Falcó E, Lopez Lopez C, Aranda E, Jones F, Sikri V, Nuciforo P, Fasani R, Tabernero J, Montagut C, Azuara D, Dienstmann R, Salazar R, Vivancos A (2017) Concordance of blood- and tumor-based detection of RAS mutations to guide anti-EGFR therapy in metastatic colorectal cancer. Ann Oncol 28:1294-1301. https://doi.org/10.1093/annonc/mdx112 
12. Vidal J, Muinelo L, Dalmases A, Jones F, Edelstein D, Iglesias M, Orrillo M, Abalo A, Rodríguez C, Brozos E, Vidal Y, Candamio S, Vázquez F, Ruiz J, Guix M, Visa L, Sikri V, Albanell J, Bellosillo B, López R, Montagut C (2017) Plasma ctDNA RAS mutation analysis for the diagnosis and treatment monitoring of metastatic colorectal cancer patients. Ann Oncol 28:1325-1332. https://doi.org/10. 1093/annonc/mdx 125

13. Normanno N, Esposito Abate R, Lambiase M, Forgione L, Cardone C, Iannaccone A, Sacco A, Rachiglio AM, Martinelli E, Rizzi D, Pisconti S, Biglietto M, Bordonaro R, Troiani T, Latiano TP, Giuliani F, Leo S, Rinaldi A, Maiello E, Ciardiello F, CAPRIGOIM Investigators (2018) RAS testing of liquid biopsy correlates with the outcome of metastatic colorectal cancer patients treated with first-line FOLFIRI plus cetuximab in the CAPRI-GOIM trial. Ann Oncol 29:112-118. https://doi.org/10.1093/annonc/mdx417

14. Marchetti A, Palma JF, Felicioni L, de Pas TM, Chiari R, del Grammastro M, Filice G, Ludovini V, Brandes AA, Chella A, Malorgio F, Guglielmi F, de Tursi M, Santoro A, Crinò L, Buttitta F (2015) Early prediction of response to tyrosine kinase inhibitors by quantification of EGFR mutations in plasma of NSCLC patients. J Thorac Oncol 10:1437-1443. https://doi.org/10.1097/JTO. 000000000000643

15. Oxnard GR, Thress KS, Alden RS, Lawrance R, Paweletz CP, Cantarini M, Yang JCH, Barrett JC, Jänne PA (2016) Association between plasma genotyping and outcomes of treatment with Osimertinib (AZD9291) in advanced non-small-cell lung Cancer. J Clin Oncol 34:3375-3382. https://doi.org/10.1200/JCO.2016.66. 7162

16. Merker JD, Oxnard GR, Compton C, Diehn M, Hurley P, Lazar AJ, Lindeman N, Lockwood CM, Rai AJ, Schilsky RL, Tsimberidou AM, Vasalos P, Billman BL, Oliver TK, Bruinooge SS, Hayes DF, Turner NC (2018) Circulating tumor DNA analysis in patients with cancer: American Society of Clinical Oncology and College of American Pathologists Joint Review. Arch Pathol Lab Med 142: 1242-1253. https://doi.org/10.5858/arpa.2018-0901-SA

17. Heitzer E, Haque IS, Roberts CES, Speicher MR (2019) Current and future perspectives of liquid biopsies in genomics-driven oncology. Nat Rev Genet 20:71-88. https://doi.org/10.1038/s41576018-0071-5

18. Odogwu L, Mathieu L, Goldberg KB, Blumenthal GM, Larkins E, Fiero MH, Rodriguez L, Bijwaard K, Lee EY, Philip R, Fan I, Donoghue M, Keegan P, McKee A, Pazdur R (2018) FDA benefit-risk assessment of Osimertinib for the treatment of metastatic non-small cell lung Cancer harboring epidermal growth factor receptor T790M mutation. Oncologist 23:353-359. https://doi.org/ 10.1634/theoncologist.2017-0425

19. Warren JD, Xiong W, Bunker AM, Vaughn CP, Furtado LV, Roberts WL, Fang JC, Samowitz WS, Heichman KA (2011) Septin 9 methylated DNA is a sensitive and specific blood test for colorectal cancer. BMC Med 9(133). https://doi.org/10.1186/17417015-9-133

20. ISO 15189:2012 - Medical laboratories - Requirements for quality and competence. https://www.iso.org/standard/56115.html. Accessed 28 Jan 2019

21. Snyder MW, Kircher M, Hill AJ, Daza RM, Shendure J (2016) Cell-free DNA comprises an in vivo nucleosome footprint that informs its tissues-of-origin. Cell 164:57-68. https://doi.org/10.1016/ j.cell.2015.11.050

22. Pérez-Barrios C, Nieto-Alcolado I, Torrente M, Jiménez-Sánchez C, Calvo V, Gutierrez-Sanz L, Palka M, Donoso-Navarro E, Provencio M, Romero A (2016) Comparison of methods for circulating cell-free DNA isolation using blood from cancer patients: impact on biomarker testing. Transl Lung Cancer Res 5:665-672. https://doi.org/10.21037/tlcr.2016.12.03

23. Mauger F, Dulary C, Daviaud C, Deleuze JF, Tost J (2015) Comprehensive evaluation of methods to isolate, quantify, and characterize circulating cell-free DNA from small volumes of plasma. Anal Bioanal Chem 407:6873-6878. https://doi.org/10.1007/ s00216-015-8846-4

24. Sorber L, Zwaenepoel K, Deschoolmeester V, Roeyen G, Lardon F, Rolfo C, Pauwels P (2017) A comparison of cell-free DNA isolation kits. J Mol Diagnostics 19:162-168. https://doi.org/10.1016/j. jmoldx.2016.09.009

25. Markus H, Contente-Cuomo T, Farooq M, Liang WS, Borad MJ, Sivakumar S, Gollins S, Tran NL, Dhruv HD, Berens ME, Bryce A, Sekulic A, Ribas A, Trent JM, LoRusso PM, Murtaza M (2018) Evaluation of pre-analytical factors affecting plasma DNA analysis. Sci Rep 8(7375). https://doi.org/10.1038/s41598-018-25810-0

26. Norton SE, Lechner JM, Williams T, Fernando MR (2013) A stabilizing reagent prevents cell-free DNA contamination by cellular DNA in plasma during blood sample storage and shipping as determined by digital PCR. Clin Biochem 46:1561-1565. https://doi. org/10.1016/j.clinbiochem.2013.06.002

27. Crowley E, Di Nicolantonio F, Loupakis F, Bardelli A (2013) Liquid biopsy: monitoring cancer-genetics in the blood. Nat Rev Clin Oncol 10:472-484. https://doi.org/10.1038/nrclinonc.2013. 110

28. Levy B, Hu ZI, Cordova KN, Close S, Lee K, Becker D (2016) Clinical utility of liquid diagnostic platforms in non-small cell lung Cancer. Oncologist 21:1121-1130. https://doi.org/10.1634/ theoncologist.2016-0082

29. Rolfo C, Mack PC, Scagliotti GV, Baas P, Barlesi F, Bivona TG, Herbst RS, Mok TS, Peled N, Pirker R, Raez LE, Reck M, Riess JW, Sequist LV, Shepherd FA, Sholl LM, Tan DSW, Wakelee HA, Wistuba II, Wynes MW, Carbone DP, Hirsch FR, Gandara DR (2018) Liquid biopsy for advanced non-small cell lung Cancer (NSCLC): a statement paper from the IASLC. J Thorac Oncol 13: 1248-1268. https://doi.org/10.1016/j.jtho.2018.05.030

30. Schwarzenbach H, Hoon DSB, Pantel K (2011) Cell-free nucleic acids as biomarkers in cancer patients. Nat Rev Cancer 11:426-437. https://doi.org/10.1038/nrc3066

31. Luo J, Shen L, Zheng D (2014) Diagnostic value of circulating free DNA for the detection of EGFR mutation status in NSCLC: a systematic review and meta-analysis. Sci Rep 4(6269). https://doi. org/10.1038/srep06269

32. Lanman RB, Mortimer SA, Zill OA, Sebisanovic D, Lopez R, Blau S, Collisson EA, Divers SG, Hoon DSB, Kopetz ES, Lee J, Nikolinakos PG, Baca AM, Kermani BG, Eltoukhy H, Talasaz AA (2015) Analytical and clinical validation of a digital sequencing panel for quantitative, highly accurate evaluation of cell-free circulating tumor DNA. PLoS One 10:e0140712. https://doi.org/10. 1371/journal.pone.0140712

33. Paweletz CP, Sacher AG, Raymond CK, Alden RS, O'Connell A, Mach SL, Kuang Y, Gandhi L, Kirschmeier P, English JM, Lim LP, Ja nne PA, Oxnard GR (2016) Bias-corrected targeted nextgeneration sequencing for rapid, multiplexed detection of actionable alterations in cell-free DNA from advanced lung Cancer patients. Clin Cancer Res 22:915-922. https://doi.org/10.1158/10780432.CCR-15-1627-T

34. Chabon JJ, Simmons AD, Lovejoy AF, Esfahani MS, Newman AM, Haringsma HJ, Kurtz DM, Stehr H, Scherer F, Karlovich CA, Harding TC, Durkin KA, Otterson GA, Purcell WT, Camidge DR, Goldman JW, Sequist LV, Piotrowska Z, Wakelee HA, Neal JW, Alizadeh AA, Diehn M (2016) Circulating tumour DNA profiling reveals heterogeneity of EGFR inhibitor resistance mechanisms in lung cancer patients. Nat Commun 7(11815). https://doi.org/10.1038/ncomms 11815

35. Goldberg SB, Narayan A, Kole AJ, Decker RH, Teysir J, Carriero NJ, Lee A, Nemati R, Nath SK, Mane SM, Deng Y, Sukumar N, Zelterman D, Boffa DJ, Politi K, Gettinger SN, Wilson LD, Herbst RS, Patel AA (2018) Early assessment of lung Cancer 
immunotherapy response via circulating tumor DNA. Clin Cancer Res 24:1872-1880. https://doi.org/10.1158/1078-0432.CCR-171341

36. Cree IA, Deans Z, Ligtenberg MJL, Normanno N, Edsjö A, Rouleau E, Solé F, Thunnissen E, Timens W, Schuuring E, Dequeker E, Murray S, Dietel M, Groenen P, van Krieken JH (2014) Guidance for laboratories performing molecular pathology for cancer patients. J Clin Pathol 67:923-931. https://doi.org/10. 1136/jclinpath-2014-202404

37. Deans ZC, Costa JL, Cree I et al (2017) Integration of nextgeneration sequencing in clinical diagnostic molecular pathology laboratories for analysis of solid tumours; an expert opinion on behalf of IQN path ASBL. Virchows Arch 470:5-20. https://doi. org/10.1007/s00428-016-2025-7

38. den Dunnen JT, Dalgleish R, Maglott DR, Hart RK, Greenblatt MS, McGowan-Jordan J, Roux AF, Smith T, Antonarakis SE, Taschner
PEM, on behalf of the Human Genome Variation Society (HGVS), the Human Variome Project (HVP), and the Human Genome Organisation (HUGO) (2016) HGVS recommendations for the description of sequence variants: 2016 update. Hum Mutat 37:564569. https://doi.org/10.1002/humu.22981

39. Whale AS, Cowen S, Foy CA, Huggett JF (2013) Methods for applying accurate digital PCR analysis on low copy DNA samples. PLoS One 8:e58177. https://doi.org/10.1371/journal.pone.0058177

Publisher's note Springer Nature remains neutral with regard to jurisdictional claims in published maps and institutional affiliations. 